\title{
Rineloricaria osvaldoi (Siluriformes: Loricariidae): a new species of armored catfish from rio Vermelho, Araguaia basin, Brazil
}

\author{
Ilana Fichberg and Carine C. Chamon
}

\begin{abstract}
A new species of Rineloricaria Bleeker from the rio Vermelho, Araguaia basin, Goiás, Brazil is described. Rineloricaria osvaldoi, new species, can be distinguished from its congeners by the combination of the following characters: surface of thoracic area trapezoidal with greatest width between pectoral fins, up to 13 premaxillary teeth, largest body width at the section of the canal plate, anterior profile of the head of mature males semicircular in dorsal view. Although eight genera of Loricariinae are known from the rio Araguaia basin, $R$. lanceolata was only species of Rineloricaria previously reported from that basin. Therefore, the discovery of the $R$. osvaldoi increases the scenery of diversity of Loricariinae within this drainage basin.

Uma nova espécie de Rineloricaria Bleeker, proveniente do rio Vermelho, bacia do Araguaia, Goiás, Brasil, é descrita. Rineloricaria osvaldoi, espécie nova, distingue-se de suas congêneres pelos seguintes caracteres: superfície da região torácica trapezoidal com maior largura entre as nadadeiras peitorais, máximo de 13 dentes pré-maxilares, maior largura do corpo na seção da placa protadora de canal, perfil anterior da cabeça semicircular, em vista dorsal, em machos sexualmente maduros. A despeito de serem conhecidos oito gêneros de Loricariinae para a bacia do rio Araguaia, somente uma espécie de Rineloricaria era formalmente registradas para esta bacia, $R$. lanceolata. Deste modo, a descoberta de $R$. osvaldoi enriquece o cenário da diversidade de Loricariinae para esta bacia de drenagem.
\end{abstract}

Key words: Loricariinae, suckermouth catfish, Goiás State, Taxonomy.

\section{Introduction}

The genus Rineloricaria Bleeker is one of the most species-rich genera of the Loricariinae (see Ferraris, 2003) and taxonomically the most problematic one (Reis \& Cardoso, 2001; Rodriguez \& Miquelarena, 2005). The genus comprises 59 valid species (Ferraris, 2003; Knaack, 2003; Ghazzi, 2008; Rodriguez \& Reis, 2008), distributed from Panama, in Central America to Northeast Argentina. Rineloricaria species are found in a large variety of habitats, including large rivers, streams, and lagoons, associated with bottoms consisting of sand or rocks, sometimes found in marginal vegetation. They are also found to tolerate environments with a wide temperature gradient (Reis \& Cardoso, 2001).

Although there is no unique apomorphic character that can be used to diagnose the genus, Rineloricaria is diagnosed by the combination of the following characteristics: postorbital notch; short rounded papillae on the inferior lip of the mouth; seven to 15 teeth on each premaxilla; dentary teeth strong, deeply bicuspidate, and larger than the premaxillary teeth; dark-brown bars or blotches on dorsal region; and a conspicuous polygonal preanal plate, which usually contacts three other large trapezoidal plates. In addition, features associated with sexual dimorphism are useful characters to diagnose mature males of some species of the genus. Dimorphic characters usually consist in numerous hypertrophied odontodes along the sides of the head and the dorsal surface of the unbranched pectoral-fin rays, which are generally thick, short, and curved in males ( $v s$. thin, elongated and almost straight in females and immature males). Males of some species of Rineloricaria possess well-developed odontodes over all of the predorsal area, or sometimes restricted to the posterior edge of parieto-supraocciptal, as in R. formosa (Isbrücker \& Nijssen, 1979).

Although the Araguaia basin has a high diversity of fishes, specimens of Rineloricaria from this basin are poorly represented in ichthyological collections. This region has been relatively well sampled through last decades, especially when compared with other large tributaries of the Amazon basin. For a long time only $R$. lanceolata was recorded from the rio Araguaia basin (pers. obs., Fichberg) and $R$. hasemani recorded from the rio Tocantins (Ferraris, 2003, 2007). In 1966 the "Expedição do Departamento de Zoologia", collected samples from rio Vermelho, a tributary to the rio Araguaia that 
contained five specimens of an undescribed species of Rineloricaria.

In 2005 an expedition to Central Brazil collected several species of the Loricariinae including Farlowella sp., Hemiodontichthys acipenserinus (Kner,1853), Loricaria sp., Loricariichthys sp., Sturisoma sp., Rineloricaria lanceolata (Günther, 1868), and additional specimens of the Rineloricaria species collected in 1966. Other species of the Loricariidae were recorded to this expedition and represented approximately $25 \%$ of total fishes collected. From the results of these expeditions, it appears that the Loricariinae are reasonably diverse in the rio Araguaia basin and that the low diversity of Rineloricaria is accurate, rather than a sampling problem. The aim of this paper is to describe a new species of Rineloricaria from rio Vermelho.

\section{Material and Methods}

Measurements followed Boeseman (1968), Reis \& Cardoso (2001), and Rodriguez \& Miquelarena (2005) except the head width, which was measured between the canal plate. All measurements were taken point-to-point with a dial caliper under a binocular stereomicroscope. All measurements and counts of bilateral structures were obtained from the left side of the specimens, whenever possible. The body measurements are expressed as proportions of standard length (SL), except for subunits of the head, which are expressed as proportions of head length (HL). Plate counts and nomenclature follow schemes of serial homology proposed by Schaefer (1997). Opercular series nomenclature follows Schaefer (1988). Cranial osteology nomenclature follows Aquino \& Schaefer (2002). Orbital diameter on Table 1 includes postorbital notch. The meristic data in the description are expressed in range of values and followed by the mode, between parentheses.

Examined material belongs to the following institutions: Museu de Zoologia da Universidade de São Paulo (MZUSP), Instituto Nacional de Pesquisa da Amanzônia (INPA), Museu de Ciências e Tecnologia da PUCRS (MCP), Museu Paraense Emílio Goeldi (MPEG), Núcleo de Pesquisas em Limnologia, Ictiologia e Aquicultura (NUP), Academy of Natural Science of Philadelphia (ANSP), Auburn University Museum (AUM), Illinois Natural History Survey (INHS), Instituto de Limnología de La Plata (ILPLA), Universidad Mayor San Simón (UMSS), National Museum of Natural History (USMN). Rineloricaria hasemani (Isbrücker \& Nijssen, 1979) was compared through literature data. Photographs of the lectotype of $R$. latirostris (Boulenger, 1900) were examined.

\section{Results}

\section{Rineloricaria osvaldoi, new species}

Figs. 1, 2 and 3

Holotype. MZUSP 89022, male, 126.3 mm SL, Brazil, Goiás, Município Goiás, rio Araguaia basin, rio Vermelho at bridge on road GO-164, 1554'11"S 506'55"W, 23 Jun 2005; C. Chamon, M. Melo, L. M. Sousa \& L. Souza.
Paratypes. MZUSP 98544, 10, 30.1-124.1 mm SL, 1 c\&s, 91.5 $\mathrm{mm} \mathrm{SL}$, same data as the holotype. ANSP $187421,4,81.0-51.9 \mathrm{~mm}$ SL, same data as the holotype. MZUSP 89075, 8, 31.9-168.3 mm SL, Brazil, Goiás, Goiás, rio Araguaia basin, rio Bugre, drainage of rio Vermelho, at bridge on road GO-164, $25 \mathrm{~km}$ NW of Goiás,

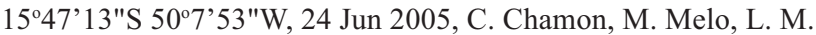
Sousa \& L. Souza. AUM 47713, 6, 72.9-63.3 mm SL, Brazil, Goiás, Goiás, rio Araguaia basin, rio Bugre, drainage of rio Vermelho, at bridge on road GO-164, $25 \mathrm{~km} \mathrm{NW}$ of Goiás; 15'47'13"S $50^{\circ} 7^{\prime} 53^{\prime \prime W}, 24$ Jun 2005, C. Chamon, M. Melo, L. M. Sousa \& L. Souza. MZUSP 4912, 5, 48.5-91.5 mm SL, Brazil, Goiás, Goiás, rio Vermelho, 14 Sep 1966, Expedição do Departamento de Zoologia.

Diagnosis. The new species can be distinguished by its congeners by the following combination of features: thoracic ventral surface trapezoidal with greatest width between pectoral fins (vs. retangular or square shape with the same width at pectoral fins and at the origin of pelvic fin); up to 13 premaxillary teeth ( $v S$. up to 10 in all congeners, except $R$. aequalicuspis with $15, R$. castroi with 15 , and $R$. uracantha with 12 ); up to 13 dentary teeth ( $v s$. up to 10 in all congeners, except $R$. aequalicuspis with $20, R$. castroi, with 12 , and $R$. uracantha with 12 ); largest width of the body at the canal plate ( $v s$. at cleithrum in $R$. altipinis, $R$. baliola, $R$. beni, $R$. castroi, $R$. heteroptera, $R$. fallax, $R$. formosa, $R$. lanceolota, $R$. latirostris, $R$. misionera, $R$. nigricauda, $R$. parva, $R$. pentamaculata, $R$. phoxocephala, $R$. quadrensis).

Description. Morphometric data of holotype and paratypes in Table 1. Head and body strongly depressed. Dorsal profile slightly concave from snout tip to dorsal-fin origin and straight from this point to caudal-fin origin. Greatest body depth at posterior border of parieto-supraocciptal; least body depth at caudal peduncle.

Head short. In dorsal view, head rounded to triangular in females and immature males with tip of snout and distal margin of opercle rounded (Fig. 3); head margin of mature males strongly rounded, shaped as semicircle (Figs. 3a-b). Snout with very small, elliptical, naked area, not reaching most anterior pore of infraorbital ramus of sensory canal.

Predorsal area weakly keeled with small odontodes covering plates; posterior margin of compound-pterotic with dark-brown spots around first pores of lateral-line canal. Eyes elliptical with large, deep postorbital notch.

Mouth opening large. Upper lip very short and separated from naked area of snout by extremely thin row of plates (sometimes absent) covered by tiny odontodes; margin of upper lip adorned with rounded papillae. Two or three rows of papillae between anteroventral border of upper lip and anterior border of premaxillary ramus; lower lip covered by irregularly sized papillae well organized and arranged concentrically around oral cavity; edge of lower lip fringed, triangular in shape. Short maxillary barbel adorned with very small papillae; teeth acute and strongly bicuspidate; dentary teeth larger than those of premaxilla; 5-13 (8) teeth on premaxilla and 5-13 (7) on dentary; accessory cusp almost same size as principal cusp.

Body covered by 26-29 (27) plates on median series, coalescent plates on 16-19 (17) and, 6-7 (6) lateral abdominal 
plates. Five longitudinal rows of plates at dorsal-fin origin. Lateral plates weakly keeled with odontodes along lateral line pores slightly better developed than those on rest of body.

Ventral region completely covered by plates, from cleithrum to caudal peduncle. Ventral plates well organized in three sections. Anterior section consisting of small quadrangular plates on pectoral girdle area, middle section includes large, trapezoidal plates between pectoral and pelvic girdles, and posterior section represented by preanal shield formed by three large plates surrounding polygonal preanal plate.
Dorsal-fin rays i, 7, pectoral-fin rays i,6, pelvic-fin rays i,5, anal-fin rays i, 5 , caudal-fin rays i, $10, i$; adpressed pectoral fin in females and immature males surpassing pelvic fin by approximately $15 \%$ of length of first unbranched ray of pelvic fin. Pelvic fin reaching insertion of anal fin. Caudal fin truncate, with short, thin filament on dorsal caudal-fin ray. Lower caudalfin ray without filament.

Color in alcohol. Dorsal surface light-brown covered by dark dots along body, more concentrated on head. Skin around

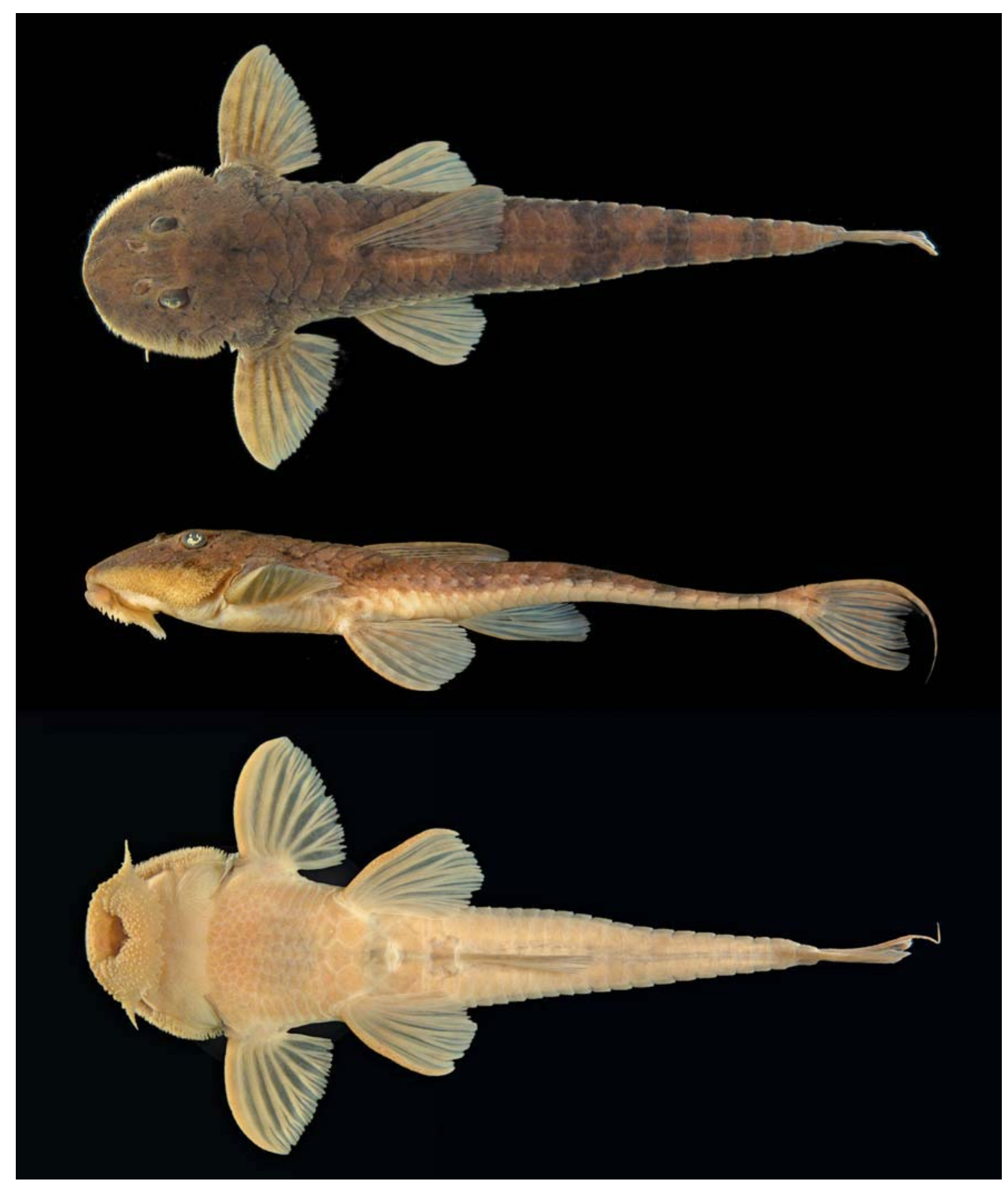

Fig. 1. Rineloricaria osvaldoi, holotype, MZUSP 89022, male, $126.3 \mathrm{~mm}$ SL; rio Vermelho, rio Araguaia basin, Brazil; dorsal, lateral and ventral views. 
pores of sensory system dark, especially around infraorbitals. Five dark brown transversal bars along body. First bar at dorsal-fin origin, second bar just posterior to dorsal-fin base and other bars located along caudal peduncle. In some specimens, bars light brown and inconspicuous.
Chromatophores widely concentrated on posterior edge of compound-pterotic forming dark conspicuous area. All fins covered by dark dots aligned through rays. Caudal fin with two vertical dark bars: broad one basally and narrow one at distal margin. Ventral surface pale ochre, without bars or dots.

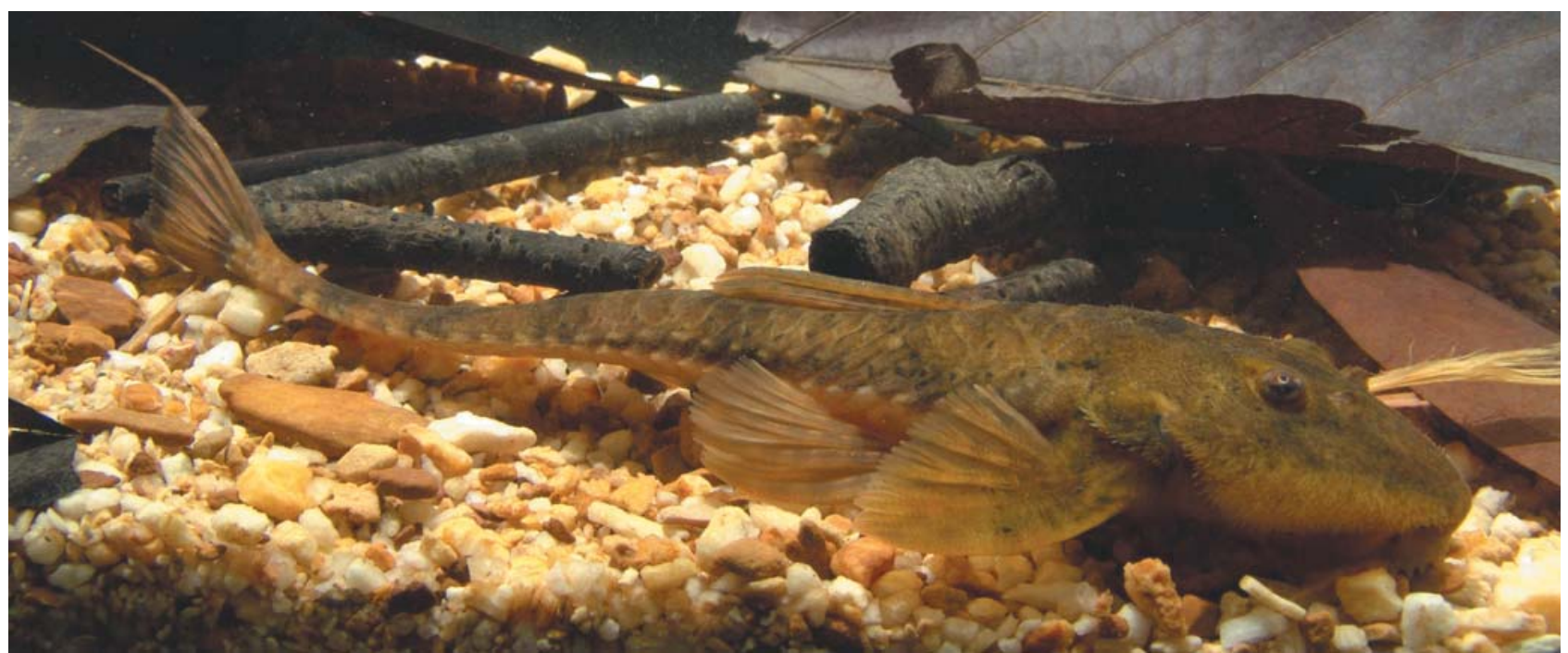

Fig. 2. Rineloricaria osvaldoi, holotype, MZUSP 89022, male, alive, prior to fixation.

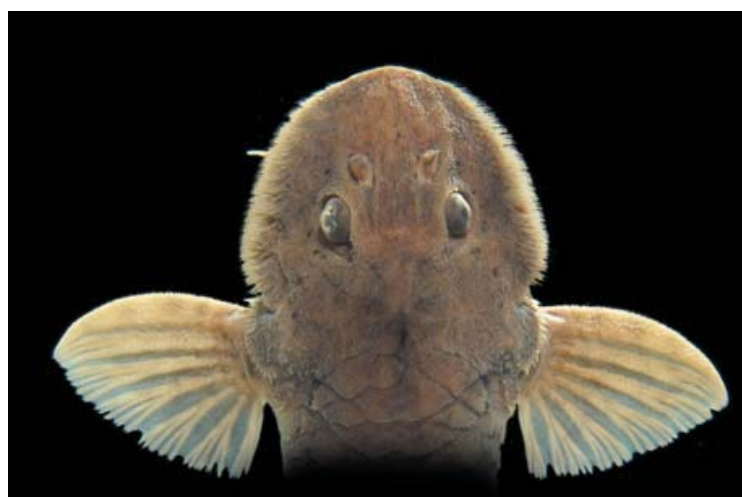

a

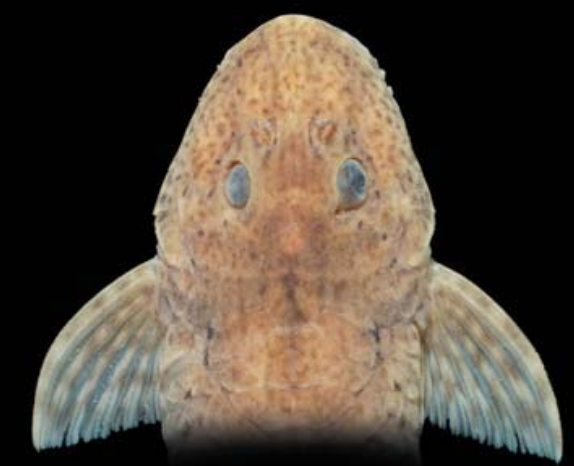

C

Fig. 3. Rineloricaria osvaldoi, dorsal and ventral views of the anterior region of the body (a and b, male, MZUSP 89022126.3 $\mathrm{mm}$ SL, c and d, female, MZUSP 89075, $125.7 \mathrm{~mm} \mathrm{SL}$ ).

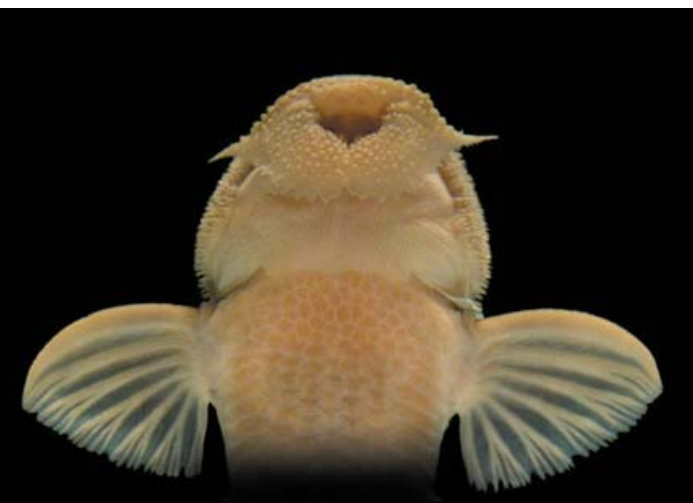

b

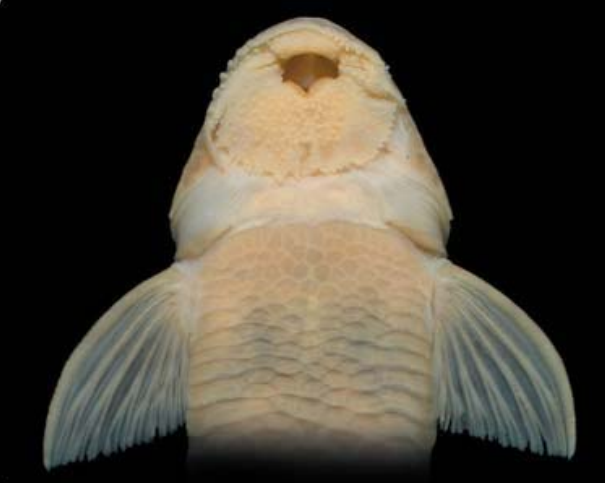

d 
Sexual dimorphism. Head margin of mature males rounded, with abundant hypertrophied odontodes extending from postrostral plates to opercle, along margin of head (see Fig. 3a); pectoral-fin unbranched ray thick, curved and shorter than in females; unbranched pectoral-fin ray and first four branched rays covered dorsally by numerous, well developed odontodes.
Geographic distribution. Rineloricaria osvaldoi is only known from the rio Vermelho and it tributary, the rio Bugre, in the rio Araguaia basin, Brazil (Figs. 4-5).

Ecological notes. The specimens were collected in clear water over a sand bottom with some rocks, at the altitude of approximately 496 meters above sea level. Both expeditions

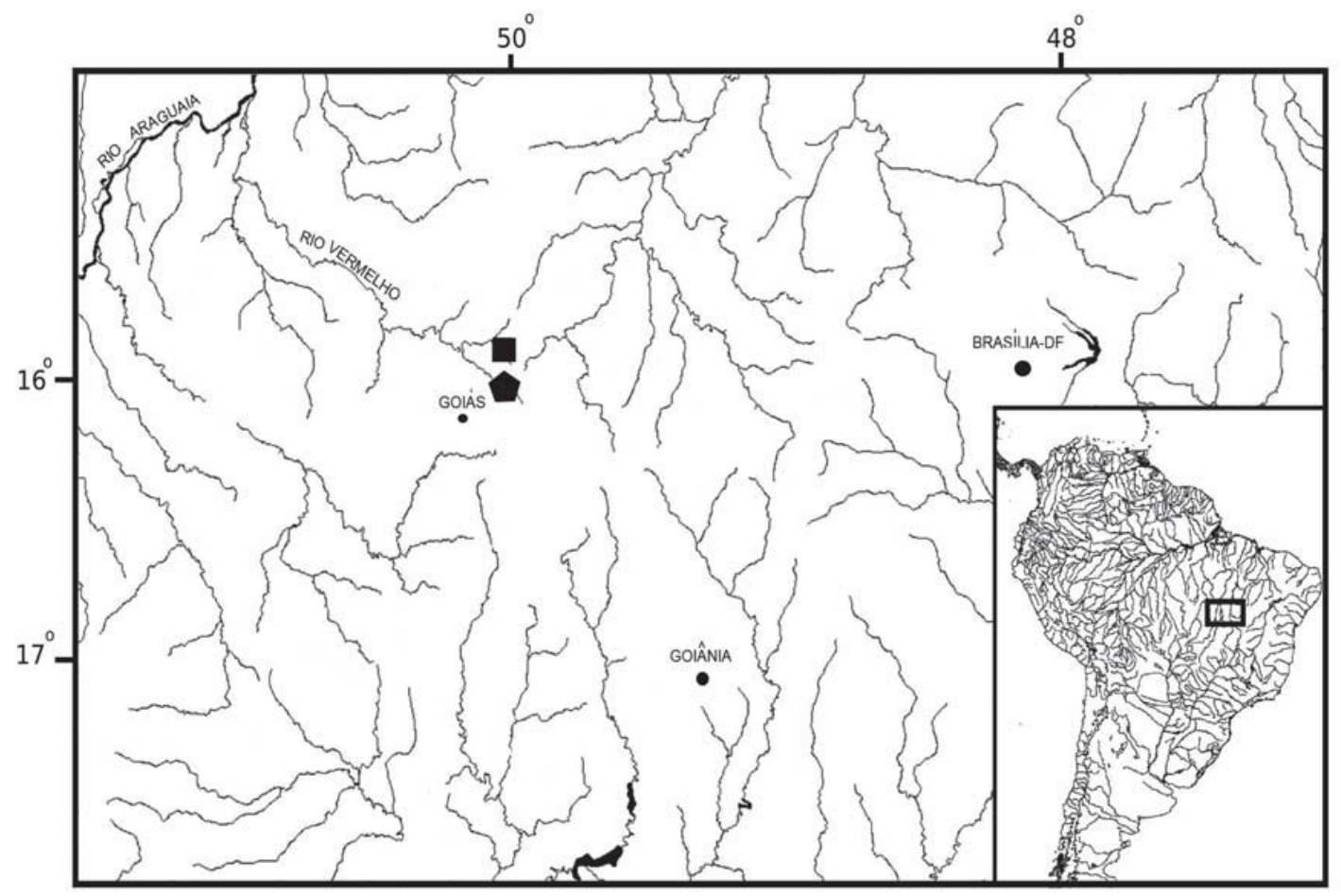

Fig. 4. Distribution of Rineloricaria osvaldoi. Pentagon = rio Vermelho (type locality); square = rio Bugre.

Table 1. Morphometric data of Rineloricaria osvaldoi (ranges include holotype; n: number of specimens, SD: standard deviation).

\begin{tabular}{|c|c|c|c|c|c|}
\hline & $\mathrm{n}$ & Holotype & Range & Mean & SD \\
\hline Standard length (mm) & 22 & 126.3 & $30.1-168.3$ & & \\
\hline \multicolumn{6}{|c|}{ Percents of standard length } \\
\hline Head length & 22 & 23.8 & $18.4-24.7$ & 21.1 & 1.9 \\
\hline Head width & 22 & 24.4 & $19.2-24.4$ & 20.9 & 1.4 \\
\hline Predorsal length & 22 & 38.5 & $32.9-38.7$ & 35.4 & 1.6 \\
\hline Dorsal unbranched ray length & 22 & 21.3 & $18.7-22.1$ & 20.6 & 0.9 \\
\hline Anal unbranched ray length & 22 & 18.1 & $15.9-18.6$ & 17.4 & 0.8 \\
\hline Pectoral unbranched ray length & 22 & 18.4 & $15.8-19.7$ & 17.6 & 0.9 \\
\hline Pelvic unbranched ray length & 22 & 17.4 & $14.5-17.7$ & 16.3 & 0.9 \\
\hline Upper caudal ray & 21 & 36.9 & $13.8-39.5$ & 24.7 & 0.6 \\
\hline Lower caudal ray & 22 & 15.1 & $13.3-18.1$ & 16.3 & 1.3 \\
\hline Thoracic length & 21 & 15.1 & $12.7-16.9$ & 14.5 & 1.2 \\
\hline Abdominal length & 22 & 16.5 & $13.2-17.6$ & 15.4 & 1.1 \\
\hline Cleithral width & 22 & 23.2 & $18.4-23.3$ & 20.0 & 1.3 \\
\hline Body depth at dorsal origin & 22 & 11.7 & $9.7-13.3$ & 11.6 & 0.9 \\
\hline Body width at anal origin & 22 & 13.4 & 8.4-13.9 & 11.8 & 1.7 \\
\hline Caudal peduncle depth & 22 & 4.5 & $1.8-4.7$ & 3.7 & 0.9 \\
\hline Caudal peduncle width & 22 & 3.2 & $1.5-4.2$ & 2.4 & 0.7 \\
\hline Postanal length & 22 & 45.4 & $45.4-55.1$ & 51.8 & 2.4 \\
\hline \multicolumn{6}{|c|}{ Percents of head length } \\
\hline Snout length & 22 & 62.9 & $50.3-68.8$ & 60.0 & 5.8 \\
\hline Orbital diameter & 22 & 26.4 & $17.2-28.9$ & 24.2 & 3.3 \\
\hline Interorbital width & 22 & 31.1 & $25.2-40.5$ & 31.4 & 4.0 \\
\hline Head depth & 22 & 57.6 & $42.2-61.3$ & 51.9 & 5.0 \\
\hline Premaxilary ramus & 22 & 8.8 & $5.2-11.7$ & 8.1 & 1.5 \\
\hline
\end{tabular}




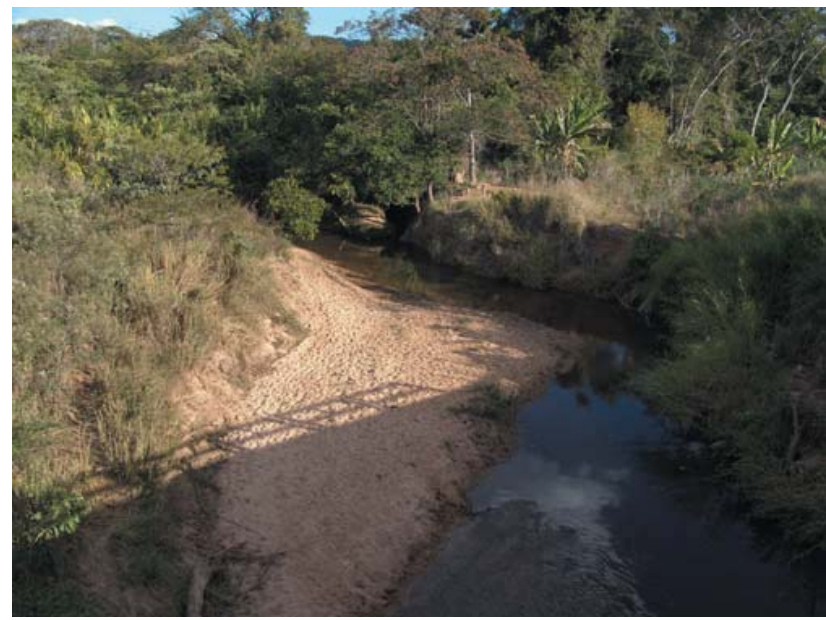

Fig. 5. Type locality of Rineloricaria osvaldoi, rio Vermelho, rio Araguaia basin, Brazil.

were carried out in dry season when the waters were low.

Etmology. The name of the new species is given in honor of Dr. Osvaldo Takeshi Oyakawa, the collection manager of the fish collection of the Museu de Zoologia da Universidade de São Paulo and also a specialist of the Loricariinae, particularly of the genus Harttia.

\section{Discussion}

Species of Rineloricaria are known from Panamá to Argentina. Although the group is widespread throughout the Neotropical region, only a few species are known to occur in some basins, such as Araguaia-Tocantins and São Francisco rivers, in contrast to South and Southeastern Brazilian drainages, in which many species of Rineloricaria are known (see Ferraris, 2003; Rodriguez \& Miquelarena, 2005; Ghazzi, 2008, and Rodriguez \& Reis, 2008). Only two other species are known from the rio Araguaia-Tocantins system, $R$. lanceolata and $R$. hasemani. Rineloricaria lanceolata is widespread in the Amazon and Paraguay basins (Ferraris, 2003 , 2007), while $R$. hasemani is apparently restricted to the lower Amazon basin, in forest streams near Belém and the rio Tocantins (Ferraris, 2003; 2007).

Rineloricaria osvaldoi is easily distinguished from $R$. lanceolata and $R$. hasemani by having a broader body (cleithral width $18.4-23.3 \%$ of SL $v s .14 .1-14.6 \%$ in R. lanceolata and $15.7 \%$ in $R$. hasemani, which only the holotype measurement is available) and on a more rounded head margin in mature males ( $v s$. triangular). In addition, $R$. hasemani has five transverse bars on the dorsum (Isbrücker, 1973), that are more conspicuous than in $R$. osvaldoi, in which the bars are lighter and sometimes inconspicuous. Rineloricaria lanceolata has a very conspicuous color pattern consisting of six black transverse bars on the dorsum, and fins well pigmented with a pale spot at the base of each and most noticeable on the pectoral fin (Isbrücker \& Nijssen, 1979).
Mature males of Rineloricaria osvaldoi have the same pattern of secondary sexual dimorphic features seen frequently in Rineloricaria species, a pattern that consists of development of odontodes on the pre-dorsal area and a thickened pectoral-fin unbranched ray. Nevertheless, the overall rounded shape of the head margin in dorsal view due, in part, to the great development of odontodes and associated tissue on the sides of the head, is unique. In most species, the males of Rineloricaria have enlarged lateral sides of the head, but never as seen in $R$. osvaldoi. A similar pattern was only observed in $R$. latirostris, a species distributed in the upper rio Paraná basin (Langeani \& Araujo, 1994). However, $R$. osvaldoi can be distinguished from $R$. latirostris by having eight to 13 premaxillary teeth (vs. five to 10 in R. latirostris); the ventral surface of the body always completely covered by plates ( $v s$. not always completely covered in R. latirostris); and the unbranched pectoral-fin ray in mature males thicker, shorter and more curved in R. latirostris than in $R$. osvaldoi. In addition, $R$. latirostris has six dark-brown transverse bars on the dorsum of the body ( $v s$. five or sometimes inconspicuous in R. osvaldoi); a thicker and more elongate caudal filament than in $R$. osvaldoi; and, the greatest body width is in the region of the cleithrum in R. latirostris (Fig. 6), whereas it is at the canal plate region in $R$. osvaldoi.

Taxonomic comments. Rineloricaria was described in 1862 by Bleeker to accommodate Loricaria lima (Kner, 1853), from an unknown type locality. In the same publication, Bleeker created Hemiloricaria to accommodate the new species $H$. caracasensis. In 1980, Isbrücker published a catalogue of the Loricariidae in which he treated Hemiloricaria as a synonym of Rineloricaria. Later, Isbrücker (2001) named two other genera, Fochiiichthys and Leliella, to accommodate three species previously included within Rineloricaria: Leliella heteroptera, Fonchiiichthys rupestris, and F. uracantus. Hemiloricaria was revalidated in that paper and 24 species were included into this genus while 18 species remained in Rineloricaria. In 2003, Ferraris (2003) included all species from Isbrücker (2001) as synonyms of Rineloricaria, at that time with 47 valid species. In 2007, Ferraris split again Rineloricaria into three genera, revalidating Hemiloricaria and Fochiiichthys, but not Leliella. Explanations for those taxonomic rearrangements were not given to support those decisions. Later, Rodriguez \& Reis (2008) suggested an explanation to consider both Hemiloricaria and Rineloricaria valid, based mainly in some external morphological characters and the distribution of the included species. In summary, Hemiloricaria corresponds to the more widely distributed genus, found throughout South America, except in upper Paraná basin and Atlantic coastal drainages. In addition, Hemiloricaria has a narrow body, unbranched caudal-fin rays and sometimes rays of the dorsal and ventral-fins prolonged as a filament, and the abdominal area completely plated. It is usually darker than Rineloricaria, with dark blotches over the body, and the sexually dimorphic characters normally consist of "hypertrophied odontodes over the top of the head, 


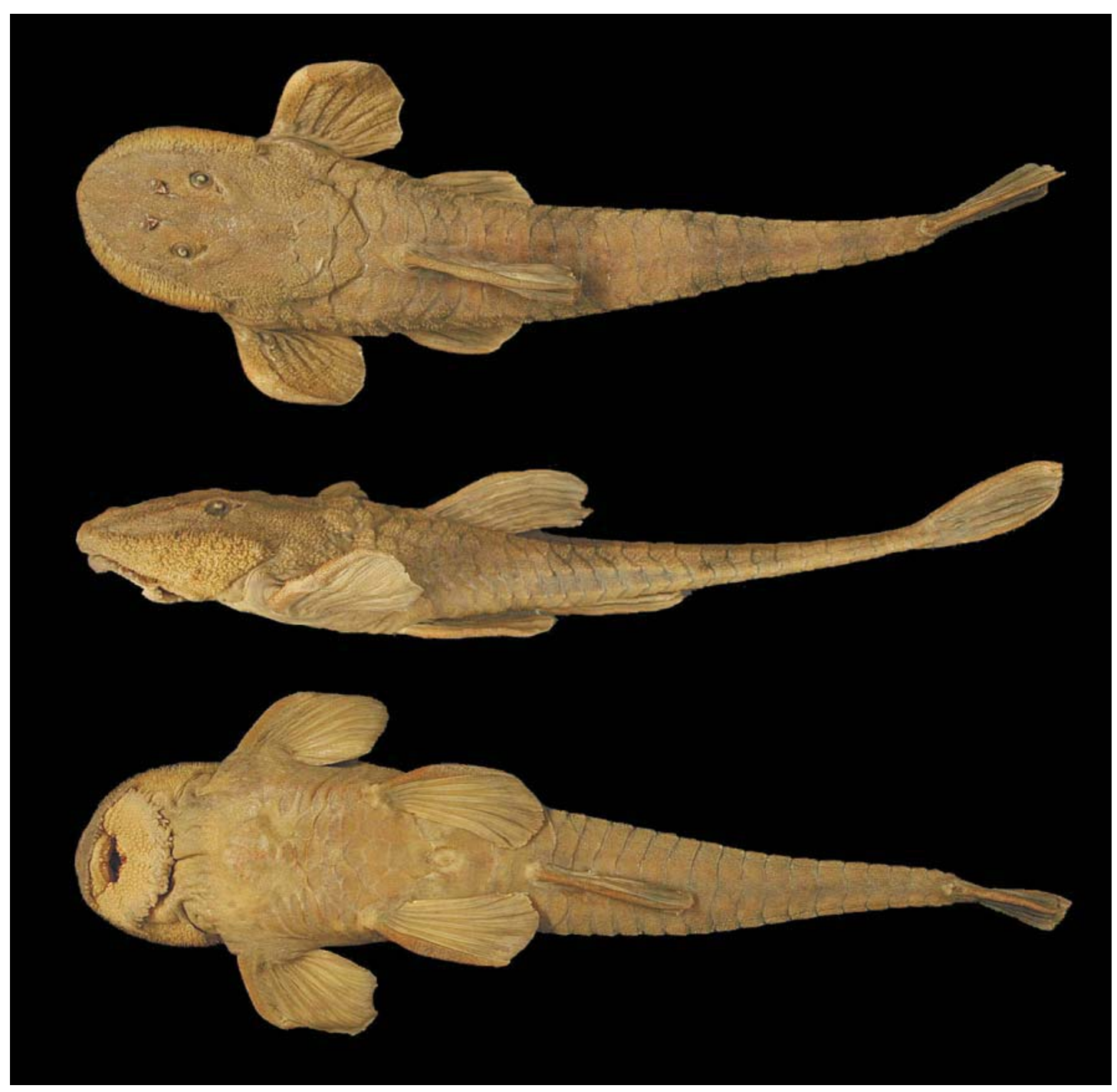

Fig. 6. Rineloricaria latirostris, lectotype, BMNH 1899.12.18.6, 228 mm SL (photo by C. Zawadzki); dorsal, lateral and ventral views.

from the interorbital region to the predorsal area", and on the cheeks. On the other hand, according to these authors, Rineloricaria is distributed only along rio Paraná basin and Atlantic costal drainages from Uruguay to Northeast of Brazil. The genus is characterized by a wide body, unbranched caudal-fin rays without a filament (except $R$. catamarcensis, $R$. kronei, R. pentamaculata, and $R$. strigilata, which usually have a short filament), the abdominal region with a variable plate cover, light-brown as background color, with five saddle bars over the body and hypertrophied odontodes in males restricted to lateral sides of the head and pectoral fin. This classification seems to contribute to the understanding of the taxonomy of the group, especially in eastern basins. However, it appears not to be helpful to Amazonian species that have greater morphological and color diversity. The species herein described has some characters of Hemiloricaria, such as the abdominal region fully plated, and the upper caudal-fin ray prolonged as a filament. In addi- tion, it resides in the geographic distribution area of Hemiloricaria. Nevertheless, $R$. osvaldoi would belong in the Rineloricaria group by the presence of following morphological characters: wide body, dimorphic features and color pattern. Based on the information mentioned above, we decided to place the new species in Rineloricaria sensu Isbrücker (1980) that treated all species as Rineloricaria, until the relationship into the group can be tested through systematic analysis in order to support more stable taxonomic decisions.

Comparative material. Rineloricaria aequalicuspis: MZUSP 37707, 21; MZUSP 27650, 1; Rineloricaria altipinis: INHS 36102, 1; Rineloricaria baliola: MZUSP15482, 4; Rineloricaria beni: UMSS 00361, 7; UMSS 01878; Rineloricaria castroi: MZUSP 15731 (holotype); INPA 14037, 3; INPA 22123, 1; Rineloricaria cadeae: MZUSP 16087, 24; MZUSP 16084, 1; INPA 19997, 6; Rineloricaria fallax: MZUSP 
77799, 1; MCP 36503, 3, 1 c\&s; INHS 49306, 12; INHS 49488, 2; Rineloricaria formosa: MZUSP 38969 (paratypes), 2; MZUSP 38997 (paratypes), 5; MZUSP 34564, 68; MZUSP 92367, 3; MZUSP 93309, 2; INPA 9916, 3; INPA 17958, 3; INPA 24666, 2, 1 c\&s; MPEG 2505, 3; Rineloricaria heteroptera: MZUSP 38954 (p), 7; MZUSP 88785, 12; MZUSP 88974, 10; MZUSP 88996, 24; INPA 25446, 2; INPA 25862, 2; MPEG 4940, 1; Rineloricaria lanceolata: MZUSP 23445, 18; MZUSP 24131, 56; MZUSP 81379, 9; MZUSP 89303, 29; MZUSP 93305, 1; Rineloricaria latirostris: MZUSP 3107, 20; MZUSP 2177, 11; MZUSP 22844, 1; MZUSP 43506, 1, c\&s; MZUSP 43508, 1; MZUSP 87951, 9; MZUSP 88334, 2; MZUSP 88510, 3; MZUSP 89407, 2; MZUSP 89419, 5; Rineloricaria microlepidogaster: MCP 26758, 17, 1 c\&s; MCP 34752, 5; Rineloricaria misionera: ILPLA 1190 (p), 3; I LPLA 1546 (p), 1; LPLA 1681 (p), 1; Rineloricaria nigricauda: MNRJ 19560, 8, 1 c\&s; Rineloricaria parva: MZUSP 54225, 3; MZUSP 54226, 3; MZUSP 95009, 127; NUP 4365, 14; Rineloricaria pentamaculata: MZUSP 38892 (h), 2; NUP 3727, 3; Rineloricaria phoxocephala: INPA 22074, 4; INPA 25864, 1; Rineloricaria quadrensis: MZUSP 37704, 3; MCP 11963, 3; MCP 19456, 8; Rineloricaria uracantha: INHS 53230, 3.

\section{Acknowledgments}

We are grateful to Osvaldo T. Oyakawa for his support and encouragement in these last years on our study on loricariids at MZUSP. We also thank José Birindelli for his careful comments and suggestions on the manuscript; Flávio T. C. Lima for the biogeography explanations; Leandro M. Sousa, Marcelo Melo and Leslie Souza for collecting the specimens; Leandro M. Sousa and Eduardo Baena for help with the illustrations; the project All Catfish Species Inventory, National Science Foundation (funding proposal 04-46), for a grant to the field work in Central Brazil Expedition-CBE. The authors were financially supported by Fundação de Amparo à Pesquisa do Estado de São Paulo - FAPESP (grant 04/018395 to I. Fichberg) and Conselho Nacional de Desenvolvimento Científico e Tecnológico - CNPq (grant 142697/2007-9 to C. C. Chamon).

\section{Literature cited}

Aquino, A. E. \& S. A. Schaefer. 2002. The temporal region of the cranium of loricarioid catfishes (Teleostei: Siluriformes): morphological diversity and phylogenetic significance. Zoologischer Anzeiger, 241: 223-224.

Boeseman, M. 1968. The genus Hypostomus Lacépède, 1803, and its Surinam representatives (Siluriformes, Loricariidae). Zoologische Verhandelingen, 99: 1-89.
Boulenger, G. A. 1900. Descriptions of three new species of siluroid fishes from southern Brazil. Annals and Magazine of Natural History, 5(26): 165-166.

Ferraris, C. J. 2003. Subfamily Loricariinae (Armored catfishes). Pp. 330-350 in: Reis, R. E., S. O. Kullander \& C. J. Ferraris Jr. (eds). Check List of Freshwater Fishes of South and Central America. Porto Alegre, Edipucrs. 729p.

Ferraris, C. J. 2007. Checklist of catfishes, recent and fossil (Osteichthyes: Siluriformes), and catalogue of siluriform primary types. Zootaxa, 1418: 1-628.

Fowler, W. H. 1954. Os peixes de água doce do Brasil. Arquivos de Zoologia do Estado de São Paulo, 9: 82-246.

Ghazzi, M. S. 2008. Nove espécies novas do gênero Rineloricaria (Siluriformes, Loricariidae) do rio Uruguai, do sul do Brasil. Iheringia, Ser. Zoologia, 98(1): 100-122.

Isbrücker, I. J. H. 1973. Redescription and figures of the South American catfish Rineloricaria lanceolata (Günter, 1868) (Pisces, Siluriformes, Loricariidae). Beaufortia, 21: 75-89.

Isbrücker, I. J. H. 1980. Classification and catalogue of the mailed Loricariidae (Pisces, Siluriformes). Verslagen en Technische Gegevens, 22: 1-181.

Isbrücker, I. J. H. \& H. Nijssen. 1979. Three new South American mailed catfishes of the genera Rineloricaria and Loricariichthys (Pisces, Siluriformes, Loricariidae). Bijdragen Tot de Dierkunde, 48(2): 191-211.

Knaack, J. 2003. Ein neuer prachthexenwels aus Paraguay: Hemiloricaria aurata n. sp. (Pisces, Siluriformes, Loricariidae). Aquaristik aktuell, 1: 56-61.

Langeani, F. \& R. B. Araujo. 1994. O gênero Rineloricaria Bleeker, 1862 (Ostariophysi, Siluriformes) na bacia do rio Paraná superior: Rineloricaria pentamaculata sp. n. e Rineloricaria latirostris (Boulenger, 1900). Comunicações do Museu de Ciências da PUCRS, Série Zoologia, 7: 151-166.

Reis, R. E. \& A. R. Cardoso. 2001. Two new species of Rineloricaria from southern Santa Catarina and northeastern Rio Grande do Sul, Brazil (Teleostei: Loricariidae). Ichthyological Exploration of Freshwaters, 12(4): 319-332.

Rodriguez, M. S. \& A. M. Miquelarena. 2005. A new species of Rineloricaria (Siluriformes: Loricariidae) from the Paraná and Uruguay River basins, Misiones, Argentina. Zootaxa, 945: 1-15.

Rodriguez, M. S. \& R. E. Reis. 2008. Taxonomic review of Rineloricaria (Loricariidae: Loricariinae) from the Laguna dos Patos drainage, Southern Brazil, with the descriptions of two new species and recognition of two species groups. Copeia, 2008(2): 333-349.

Schaefer, S. A. 1988. Homology of the opercular series in the loricarioid catfishes (Pisces: Siluroidei). Journal of Zoology, 214: 81-93.

Schaefer, S. A. 1997. The Neotropical cascudinhos: systematics and biogeography of the Otocinclus catfishes (Siluriformes: Loricariidae). Proceedings of the Academy of Natural Sciences of Philadelphia, 148: 1-120.

Accepted July, 2008 Published September 30, 2008 